\title{
PERLOV-GUERIN: RESONANCIAS
}

Luz Marina Ortiz Avilés

Universidad de Córdoba

Data de recepción: 2019-08-20

Data de recepción: 2020-06-01

Contacto autora: |02oravl@uco.es

ORCID: https://orcid.org/0000-0002-8117-9473

\section{RESUMEN}

David Perlov y José Luis Guerin convergen en lo esencial al pensar el cine no en relación con lo industrial sino en relación con lo artesanal: el cine como un forma de escritura. Pero no es este el único punto de encuentro entre las obras cinematográficas de estos dos directores pudiendo advertirse entre ambas otros puntos de confluencia. En este artículo trataremos, pues, de examinar la obra de sendos cineastas atendiendo a sus paralelismos, esto es rastrear aquellos elementos o rasgos del cine de Perlov que reaparecen en el cine de Guerin, así como de dilucidar la naturaleza de dicha relación.

Palabras clave: flâneur, film-diario, rostro, retrato, cotidiano

\section{ABSTRACT}

David Perlov and José Luis Guerin share common ground in that they both see cinema as a craft rather than an industry. They see cinema as a form of writing. Yet this is not the only meeting point between the oeuvre of these two directors. There exist other points of convergence. In this article, we will try to examine the work of the two directors, looking at the parallels between them and identifying which elements or characteristics of Perlov's films also appear in Guerin's works, while shedding light on the nature of this relationship.

Keywords: flâneur, film diary, face, portrait, the everyday

\section{Introducción}

David Perlov se convierte en uno de los primeros referentes del cine diario al comenzar la filmación del suyo allá por los primeros años de la década de 1970. Aunque el cine autobiográfico tiene sus antecedentes en los hermanos Lumière con cortometrajes, por ejemplo, como La comida del bebé (Repas de bébé, 1895) de Louis Lumière, el cine de Perlov -su diario- viene a sumarse y contribuir a aquellas formas cinematográficas más íntimas y personales que comenzarían a desarrollarse a finales de los años sesenta y principios de los setenta dentro del cine underground americano y el cine directo. Además, dentro del panorama cinematográfico israelí, Perlov viene a significar un punto de inflexión y ello por cuanto su diario, marcado por una fuerte tensión entre la historia personal (privada) y la historia colectiva (pública), abre un nuevo camino al cine de este país hasta entonces utilizado esencialmente como herramienta propagandista.

Inmigrante de Brasil, Perlov se convierte en el padre del cine moderno israelí. Su cine ha influenciado a generaciones de estudiantes -más aún a través de su labor docente-, ha sido proyectado en el Tel Aviv Museum of Art, ha sido seguido por la crítica como ningún otro filme israelí y, sin embargo, no es hasta el fallecimiento del cineasta en 2003 que su figura alcanza la proyección y la visibilidad internacional' que merece, por reivindi- 
cación de su mujer Mira, su hija Yael y exalumnos y amigos del cineasta como Ariel Schweitzer².

En su 'Diario', "Perlov ofrece un punto de vista personal que no elude la reflexión moral ni estética" (Merino 2007, 28); se trata éste de una obra sencilla, modesta, que no renuncia a la belleza y que representa una cartografía del yo en el mundo en tanto diario de registros que refleja la forma en que el autor transita y vive los espacios que habita. A este respecto se encuentra emparentado en el panorama cinematográfico español con el filme Guest (2010) del cineasta barcelonés José Luis Guerin que también se trata de un diario de registros que resulta una cartografía subjetiva de los lugares por los que el cineasta transita. Además, como el cine de Perlov, también el cine de Guerin es un cine sencillo, depurado, reflexivo, poético... Ambos cineastas convergen en su entendimiento del medio cinematográfico como una forma de escritura pero más allá de estos puntos esenciales de confluencia entre las cinematografías de ambos se revelan una serie de paralelismos en su discurrir personal y profesional y una serie de correspondencias entre algunos de los rasgos y elementos que definen su cine, que exponen una cierta familiaridad de Guerin con la obra del cineasta de origen israelí.

Como Perlov, tampoco Guerin ha cosechado la proyección y visibilidad que merece -ni nacional, ni internacional- siendo escasa la bibliografía existente sobre la vida y obra de ambos cineastas. Además entre la bibliografía existente ninguna aborda un estudio relativo a la obra de estos dos directores. En este artículo nos proponemos arrojar algo más de luz sobre las obras de Perlov y Guerin centrándonos para ello en los paralelismos que se evidencian entre ambas. Así, partiendo para este estudio de la base de que el cineasta barcelonés conoce la obra de Perlov-como veremos, así lo revelan las imágenes- trataremos de examinar la obra de ambos, rastreando aquellos elementos y rasgos de la obra del cineasta de origen israelí que reaparecen en el cine de Guerin, así como también de dilucidar la naturaleza de la correspondencia entre ambas.

\section{David Perlov y José Luis Guerin}

Descendiente de una familia israelí emigrada a Brasil, David Perlov (Río de Janeiro, 1930- Tel Aviv, 2003) pasa su infancia y su adolescencia en Belo Horizonte y São Paulo respectivamente, hasta que en 1950 viaja a París con el propósito de cursar los estudios de Bellas Artes. Una vez allí, y mientras cursa sus estudios, Perlov descubre a Jean Vigo con su filme Cero en conducta (Zéro de conduite: Jeunes diables au collège, 1933), momento a partir del cual desarrolla una pasión por el cine. Así, Perlov empieza a frecuentar la Cinémathèque donde conoce a Henri Langlois -con quien entabla una relación de amistad y comienza a trabajar como asistente- y a Joris Ivens -con quien trabaja como editor y ayudante de dirección-.

En 1958, Perlov abandona París para instalarse junto a su mujer Mira en Israel donde residiría hasta el final de sus días. En aquel tiempo el Cine Israelí estaba dominado por filmes de carácter propagandístico ordenados fundamentalmente a ensalzar la patria o reflejar la realidad social de algunos colectivos. Se trataba pues, fundamentalmente, de un cine utilizado como instrumento por las instituciones gubernamentales y las organizaciones Sionistas. En esta atmósfera, Perlov revoluciona el documental al introducir en él subjetividad y una dimensión poética. Sin embargo, a pesar del reconocimiento obtenido por parte de la crítica, a principios de los años setenta Perlov dejaría de recibir encargos de las autoridades israelíes que además denegaban las solicitudes del cineasta. Así, en 1973, decide hacerse de un equipo de filmar básico y con los recursos mínimos comienza a trabajar en Diary (1973-1983) (Yoman (Diary), 1983), un filme «Ensa-yo» -esto es un filme híbrido entre el diario personal y el ensayo cinematográfico- donde iría documentando el día a día de su vida cotidiana junto a algunos de los dramáticos acontecimientos que determinaron aquel periodo en Israel. Por otra parte, ese mismo año, Perlov funda junto a otros el nuevo Departamento de Cine y Televisión en la Universidad de Tel Aviv tornando así la enseñanza una parte crucial de su devenir personal y artístico.

Posteriormente, en 1998, el cineasta israelí comenzaría a trabajar en Updated Diary (19901999)4 (Yoman Meudkan (1990-1999), 2001), 
entonces filmado con una pequeña cámara de vídeo; en el año 2000 completaría la edición de Anemones , un filme producido con sus alumnos de la universidad. En 2003 realizaría su último filme titulado My Stills (1952-2002) basado completamente en las fotografías tomadas por el cineasta durante un periodo de cincuenta años y que resulta a la vez una reflexión sobre la fotografía como actividad así como un homenaje a los fotógrafos que siempre admiró adquiriendo el filme el carácter de testamento al condensar una vida marcada por el amor a lo cotidiano y el amor por el arte.

José Luis Guerin (Barcelona, 1960) es un cineasta autodidacta formado en la historia del cine por su continuada presencia en la Filmoteca de Barcelona. Aunque su obra arranca a la edad de 15 años con una serie de obras en formato Super-8, no será hasta 1983 con Los motivos de Berta -su debut en $35 \mathrm{~mm}$ - que dé el salto a la profesionalidad. Los motivos de Berta captará el interés de los círculos minoritarios -crítica especializada, festivales - sin embargo la obra del cineasta barcelonés seguirá resultando inaccesible hasta 2001, año en que presenta En construcción que tuvo proyección en salas comerciales. Como el filme Anemones, de Perlov, En construcción se trata de un filme rodado con el apoyo de sus alumnos del Máster en Documental de Creación de la Universidad Pompeu Fabra de Barcelona a lo largo de dos años y medio.

En 2007 verá la luz -solo en formato DVDUnas fotos en la ciudad de Sylvia que se trata de un fotomontaje secuencial en blanco y negro y mudo construido a partir de fotografías realizadas por el cineasta. Entre septiembre de 2007 y septiembre de 2008, aprovechando los viajes promocionales del trabajo previo del director En la ciudad de Sylvia (2007), Guerin lleva a cabo un periplo por un total de cuarenta y cinco ciudades filmando con una pequeña cámara doméstica su paso por ellas. El resultado de dicho periplo será Guest un film-viaje cuyo título responde precisamente al estatuto del director durante su realización: invitado. Además, Guest supone una reflexión sobre algunos de los intereses del cineasta y también así sus cartas filmadas Correspondencia Jonas Mekas- José Luis Guerin (2011) que resultan un diálogo no entre cineastas sino entre sus filmografías, es decir, un proyecto de comunicación entre directores para que estos compartieran algunas reflexiones sobre su trabajo y aquello que lo motiva. En 2015, Guerin realiza La Academia de las Musas, su último largometraje hasta la fecha, cuya filmación también comienza en el seno de la universidad.

Por otra parte, también Guerin compaginará su actividad como cineasta con la docencia en la Universidad Pompeu Fabra de Barcelona como profesor en el Máster en Documental de Creación-, en la Escuela Internacional de Cine y Tv San Antonio de los Baños (en Cuba) -como profesor en la Maestría en Desarrollo de Proyecto Documental-, así como también impartiendo conferencias y talleres, por lo que la docencia también forma parte esencial de su actividad profesional.

\section{La flânerie en el cine de David Perlov y José Luis Guerin}

El flâneur, aquel tipo social típico del París del s.XIX que se caracterizaba por un deambular por la ciudad sin dirección ni rumbo preestablecido -esto es según un callejeo no planificado-, actividad durante la cual mantenía una actitud observadora y perceptiva con una mirada interpretativa, encuentra su manifestación en el cine de David Perlov y también así en el cine de José Luis Guerin.

El diario de David Perlov, Diary (1973-1983), se encuentra a caballo entre el diario de vida y la reflexión ensayística y ello, por cuanto los seis capítulos que lo conforman suponen tanto un registro de las vivencias cotidianas del director y los acontecimientos o circunstancias que lo rodean, como una reflexión - a través de la voz over del director, en su mayoría incluida posteriormentesobre el cine, su propia práctica autobiográfica o la convulsa historia de Israel en esos años golpeada por la guerra del Líbano o la masacre de Sabra y Chatila. No obstante, estas reflexiones no vienen tanto a dar respuestas, a dirigir la lectura de las imágenes a que acompañan, como a lanzar preguntas que ofrezcan una lectura poliédrica de las mismas, llegando incluso con ello a poner en tela de juicio su significado aparente como es el caso de los fragmentos de programas televisados que en ocasiones incluye y en los que el Estado se 
esfuerza por presentar una realidad muy alejada de la que vive su sociedad. Son ejemplo de ello las imágenes televisadas donde unos soldados dan agua a una civil que ha estado escondida durante varios días mientras el locutor comenta la solidaridad de los militares. Entonces David Perlov dirá: "¿Y a esto llamas ser humano?" (Diary (1973-1983), Chapter 1). Con esta irónica cuestión invalida la absurda exaltación realizada por el locutor y pone de relieve los esfuerzos del Estado por maquillar los terribles sucesos vividos por los civiles.

Para la filmación de este diario, la "cámaraestilográfica" de David Perlov oscila entre el interior de la casa familiar del director y el exterior, actuando la ventana como elemento de abertura a dos espacios que no pueden desligarse sino que muy por el contrario cada uno se nutre y es reflejo de las vivencias que encierra y alberga el otro, entretejiéndose.

En los diarios de Perlov el espacio urbano adquiere importancia. Diary (1973-1983) está filmado desde distintos lugares, principalmente el apartamento en Tel Aviv residencia del director pero también desde Jerusalén, París, Agios Nikolaos, Colonia, Amsterdam, Lisboa, Londres, São Paulo, Río de Janeiro o Belo Horizonte; destinos en su mayoría a los que viaja no tanto con el propósito de dar cuenta de los espacios urbanos del presente de la filmación como para buscar en ellos sus propias huellas y evocar su pasado. No obstante, también encontramos en Diary (1973-1983), y muy especialmente en el capítulo cinco, una aproximación del cineasta a la figura del flâneur. Como ocurre a este tipo social, para David Perlov la mirada constituye una experiencia fundamental. Es la suya una observación interpretativa y reflexiva que no solo no cesará a lo largo de una década, tiempo durante el cual Perlov irá realizando sus registros filmados, sino que se prolongará hasta 1999, fecha en que filma los últimos registros que posteriormente conformarán el trabajo que vendrá a servir de continuación y cierre de los diarios que aquí nos encontramos analizando y que se titularían Updated Diary (1990-1999). A su vez, el origen de esta actividad observadora tampoco se encuentra en el inicio de la filmación de estos diarios de registros sino en un trabajo anterior del director,
In Jerusalem (B'Jerushalaim, 1963) -un filme de apenas 33 minutos que se estructura a través de diez observaciones de la ciudad de Jerusalén- y, sobre todo, en un trabajo posterior de Perlov quien había sido enviado a Jerusalén para cubrir el bombardeo de Arab para la televisión. Durante la realización de aquel trabajo Perlov descubriría las posibilidades que la nueva tecnología le ofrecía. El cineasta lo explicaría así en una entrevista:

Era la primera vez que trabajaba con una cámara Arri $16 \mathrm{~mm} \mathrm{BL}$, habiendo trabajado hasta entonces en $35 \mathrm{~mm}$ lo cual es complicado y pesado y demanda una precisa puesta en escena. Yo estaba de pie sobre el tejado de un edificio en Jerusalén planificando la toma que transmitiría el bombardeo de Arab de la Agencia Judía, cuando de repente, una joven prostituta apareció. Como de otro planeta. Yo empecé a hablar con ella. Estuve a punto de olvidar para qué había venido. Su monólogo era sorprendente. Era obvio que con mi pequeña nueva cámara podía fácilmente filmarla y registrar su voz. Y me dije: "Eso es lo que debo hacer vagar con una cámara y filmar." Así es como había hecho In Jerusalem pero entonces el equipo era pesado $y$ complicado y los productores querían una película de gran presupuesto. Hoy, todo es diferente, gracias a las luminosas y rápidas cámaras, la grabación digital, la iluminación simple y los pequeños equipos (Klein, I. y Klein, U. 2006, 13).

Perlov compararía, además, el material de trabajo del cineasta -la cámara $35 \mathrm{~mm}$ y la Arri 16 mm BL-con el material y la técnica de los pintores impresionistas del s.XIX quienes pasaron del óleo a los pasteles para poder abandonar -según explicaba el director- sus talleres y salir a la calle a capturar la vida misma. Como la pintura impresionista, Diary (1973-1983) es el resultado de la actividad observadora del cineasta cámara en mano resultando especialmente interesante el quinto capítulo de este diario por cuanto en él Perlov reflexiona sobre su propia práctica como cineasta así como sobre sus intereses, aquello que mueve su trabajo: la vida misma, sin artificios. Señala Perlov:

Me permito un juego de azar. El único juego de mi agrado. ¿Atraparé algo en mi pequeño marco? ¿O no? Mi pequeña vecina, ensayando la maternidad, sabe perfectamente cuando la estoy observando. Observar se ha convertido en la esencia de mi vida. 
No en busca de una trama, de una historia. Es la imagen de un hombre corriendo la que me fascina, no la razón por la cual corre, o hacia donde. La trama, la intriga, las prefiero fuera de mi vista. [...] De vuelta a mi juego. Comienza a divertirme. ¿Pasará alguien? Para mí un movimiento diagonal generalmente tiene éxito. Afortunado nuevamente. Líneas rectas jamás me han llevado a nada. Persisto (Diary (1973-1983), Chapter 5).

La actividad de observar se ha convertido para Perlov, como para el flâneur, no solo en la clave de su trabajo sino en su forma de vivir. Pero no solo es la mirada -la observación- lo que lo aproxima a la figura del flâneur sino también su gusto por las grandes ciudades donde dice sentirse como en casa. Siente así como hogares París y Tel Aviv y en el capítulo seis confiesa como con nostalgia no entender por qué cuando era bebé lo arrancaron de la ciudad donde nació, Río de Janeiro, también una gran ciudad a propósito de la cual Perlov dirá: "la ciudad más hermosa del mundo. Río de Janeiro. No la promesa del Paraíso, sino el Paraíso mismo. Como en las postales, te saca una sonrisa. Nací en un mundo de postal. La ciudad más maravillosa del mundo" (Diary (1973-1983), Chapter 6); o revela cómo fue la primera vez que llegó a São Paulo 6 acompañado de su abuelo: tenía diez años y entonces, como en el presente de la grabación, no pudo más que observar los enormes edificios que atrapaban su mirada. La ciudad ejerce pues, una fuerte atracción sobre Perlov.

La vida en las grandes ciudades con sus enormes edificios, el tráfico y su aglomeración y muy especialmente los no lugares de aquellas, como son las estaciones de tren, han cautivado al cineasta de origen israelí hasta el punto de que durante el periodo de convalecencia tras ser sometido a una intervención quirúrgica de urgencia en Londres acabará señalando: "Estoy mejorando pero comienzo a sentirme inquieto. Ya basta de este pulcro suburbio londinense. Añoro la gran ciudad. Aquí, en Oxford street, me siento en casa" (Diary (1973-1983), Chapter 5). La quietud de una zona a las afueras de la ciudad lo altera y, por contra, en la agitación de una de las calles comerciales más concurridas de Europa encuentra el sosiego y la armonía del hogar. Cuestión esta que vuelve a ponerse de manifiesto cuando explica también en el capítulo cinco, durante un viaje en tren a Joinville Le pont a las afueras de París adonde acude semanalmente para revelar sus películas, sentirse subyugado por la naturaleza y necesitar el artificio de la ciudad para poder filmar a gusto.

Además, como el flâneur, desea deambular por las ciudades sin rumbo, sin una dirección preestablecida y perderse en ellas aunque a diferencia de aquella figura de principios del siglo XIX su callejeo no será a pie, o no exclusivamente, sino en taxi, medio que prefiere. El taxi le posibilita por un lado recorrer la ciudad dejando a voluntad del taxista el trayecto y por otro introducir en sus filmaciones el azar, pues sus registros vendrán definidos por el ritmo casual de los semáforos o un atasco imprevisto. Perlov explicará en los diarios el modo de proceder: "Recuerdo una vez, durante mis días de estudiante en París, cuando con todos mis ahorros tomé un taxi, diciéndole al taxista: "Lléveme adonde quiera pero no me diga dónde estamos." Tuve efectivo suficiente para cuatro horas" (Diary (1973-1983), Chapter 5). El ritmo del taxi marcado por el tráfico -su avance, su detención- determina los acontecimientos que el cineasta va a observar y registrar con su cámara permitiendo así que el azar se introduzca nuevamente en su filmación.

Con la Arri $16 \mathrm{~mm} \mathrm{BL}$, pues, Perlov se adapta en su forma de ejecución a los contenidos que quiere expresar. La representación de acontecimientos fugaces en el espacio público requiere técnicas rápidas como el esbozo, el croquis y la caricatura; todas ellas modalidades de trazo rápido que permiten al artista observador -al flâneur-capturar la vida misma -sus observaciones, sus impresiones...- durante su transcurso. Perlov concibe el cine como una forma de escritura, tratándose la cámara para él de un cuaderno de notas, de la herramienta del escritor. Así, el cine se acerca en él a la aspiración anunciada por Alexandre Astruc en su Nacimiento de una nueva vanguardia: la «Caméra-stylo» donde según el autor el cine: "Se convierte poco a poco en una lengua. Un lenguaje, es decir, una forma en la cual y mediante la cual un artista puede expresar su pensamiento, por muy abstracto que sea, o traducir sus obsesiones exactamente igual 


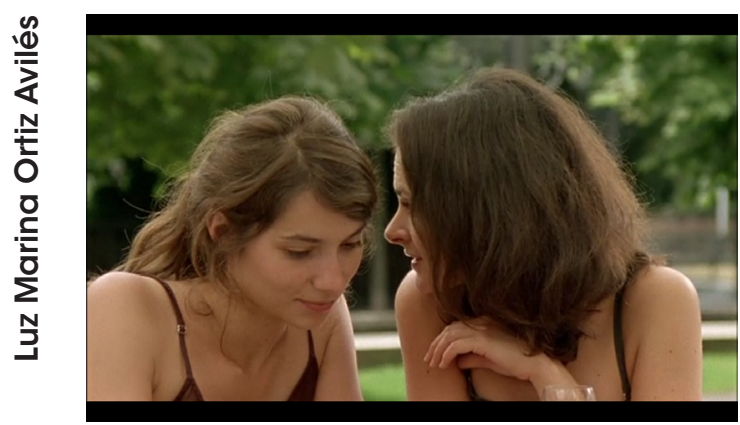

Fig. 1. José Luis Guerin, En la ciudad de Sylvia, 2007

como ocurre actualmente con el ensayo o con la novela" (Astruc 1993, 221).

Esta concepción del cine como una forma de escritura que es la esencia del cine de Perlov, también define el cine de Guerin. En la filmografía del cineasta barcelonés podemos encontrar varias obras en que la flânerie se pone de manifiesto en algún modo. Así, nos encontramos por un lado con la representación visual de este tipo social en la pantalla como es el caso del filme En la ciudad de Sylvia donde Xavier Lafitte es identificado como un flâneur y, por otro, con la identificación del registro visual de la cámara con la flânerie urbana y por extensión del cineasta como flâneur como son el caso, por ejemplo, del filme Unas fotos en la ciudad de Sylvia realizado a partir de las fotografías que tomara Guerin llevando a cabo la práctica del fotógrafo-flâneur y sobre todo, y más importante para el análisis comparativo que aquí estamos llevando a cabo, su diario de registros Guest y Carta a Jonas Mekas $n^{\circ} 1$ y Carta a Jonas Mekas $n^{\circ} 4$ de Correspondencia Jonas Mekas- J.L. Guerin; obras, como decimos, que adquieren mayor interés por cuanto en ellas Guerin es identificado como un flâneur cámara en mano: en Guest al iniciar su paso errante por distintos emplazamientos geográficos ${ }^{7}$ capturando con su pequeña videocámara todo cuanto acontece a su alrededor y llama su atención y en Carta a Jonas Mekas $n^{\circ} 1$ por cuanto el cineasta desvela la práctica que desde Guest ha venido asumiendo a la vez que se inscribe en el filme como tal tipo social. Esto último tiene lugar a través de la imagen de una hoja blanca donde aparece escrita la palabra flâneur en el instante exacto en que la voz over de Guerin da cuen-

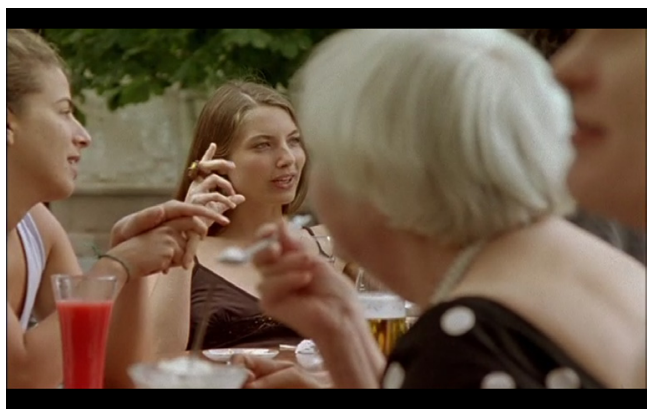

Fig. 2. José Luis Guerin, En la ciudad de Sylvia, 2007

tas al tú-destinatario de la carta del trabajo que como cineasta ha venido realizando pero, como decimos, no solo asume la práctica de este tipo social sino que también se inscribe como tal en el filme al grabar su propia sombra proyectada en el suelo mientras deambula por el espacio público. Además, en ambas obras el cineasta barcelonés expone su concepción del cine, no otra que su pensamiento como una forma de escritura siendo expuesto desde el inicio de las mismas a través de la imagen de una página en blanco en Guest y en Carta a Jonas Mekas $n^{\circ} 1$ y de una pantalla de cine -a modo de lienzo de pintura- en Carta a Jonas Mekas $n^{\circ} 4$; papel y "lienzo" que aguardan convertirse en soporte de una escritura no con lápiz o pintura sino una escritura cinematográfica convirtiéndose la ciudad, también en ambos casos, en pura fuente de expresión.

\section{Los rostros: su observación, su retrato}

La fascinación de Perlov por los rostros surgiría desde su niñez en los andenes de la Estação da Luz de São Paulo a donde llegó desde Belo Horizonte con su abuelo y a donde acudiría con asiduidad sentándose a esperar el tren mientras fijaba encuadres que dibujar. El tren solía transportar refugiados del norte del país que huían de la sequía, la hambruna, la anemia y la tuberculosis a la que ésta había dado paso, ejerciendo el rostro de aquellos una fuerte atracción sobre el joven Perlov que en el capítulo seis de este diario llegaba a declarar que aquel mundo se trataba de una droga para él. La multitud, el ajetreo de la muchedumbre así como los rostros del dolor y la desesperación ${ }^{8}$ producirían una huella tal sobre el joven Perlov que perduraría toda su vida. 


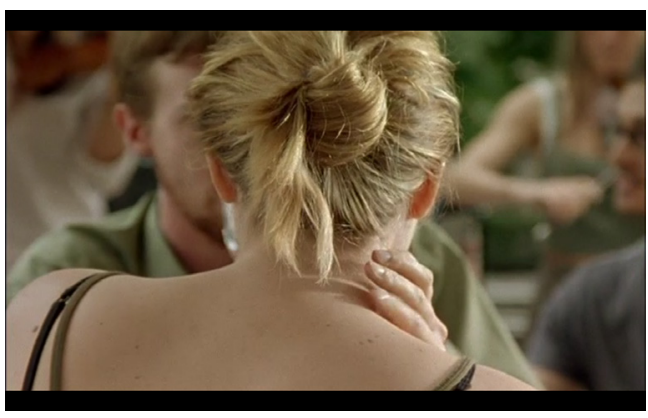

Fig. 3. José Luis Guerin, En la ciudad de Sylvia, 2007

A consecuencia del interés del cineasta en la muchedumbre -en sus rostros-, su diario está cargado en su mayor parte de presencias humanas. Conocidos y familiares del cineasta así como desconocidos que habitan el espacio público que aquel recorre pueblan las tomas que Perlov filma tanto en interiores como en exteriores. Solo cuando el ánimo del cineasta flaquea o directamente se encuentra abatido -como ocurre, por ejemplo, en el capítulo dos-, Perlov realizará tomas en picado del suelo del hogar familiar o, en el espacio público, del suelo y los pies de los viandantes. El desánimo del cineasta torna en sus imágenes vacío figurativo y aunque Perlov sale al espacio público forzándose a mantener el contacto con la realidad, como señala la voz over del cineasta, no es capaz de ver más rostros humanos.

Por su parte, José Luis Guerin está muy interesado en el cine como un arte del retrato. Con la realización de sus tres obras Unas fotos en la ciudad de Sylvia, En la ciudad de Sylvia y Las mujeres que no conocemos (2007) que giran en torno al encuentro entre un flâneur y una fugitiva daba cuenta de este interés pues éstas suponen una reflexión en torno a la fragilidad de la imagen-recuerdo, la fugacidad del rostro y el retrato como único testimonio fiable y duradero de la fisionomía del ser humano. Con la excusa de la búsqueda de una mujer fugitiva, Guerin nos lleva a recorrer distintas ciudades ${ }^{9}$ posando la cámara en los rostros de las mujeres -generalmente beIlas- que las habitan y que recuerdan al flâneur a la mujer anhelada. También su filme En construcción dará cuenta del interés del director en el cine como un arte del retrato pues aunque el filme trata de dar cuenta de la mutación sufrida por el

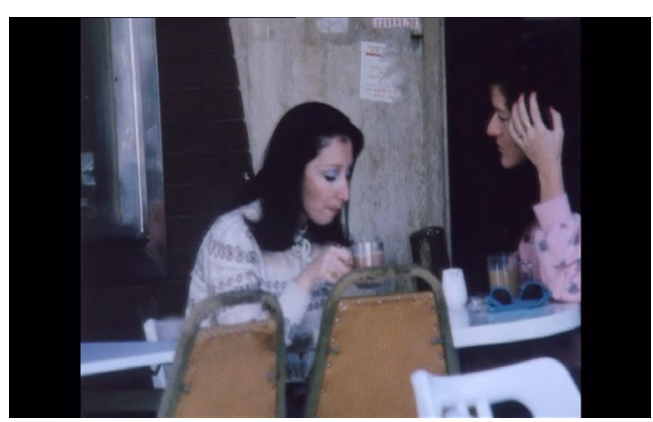

Fig. 4. David Perlov, Diary (1973-1983), Parte 1, 1974-1975

barrio de El Raval de Barcelona, objeto de un plan de reforma urbanística, no será a través de sus calles, plazas, avenidas, etc. que el cineasta nos lo muestre sino a través de los rostros que lo habitan y a su juicio lo representan. Del mismo modo, La academia de las musas surge de un espacio y los rostros que lo habitan, esto es un aula de Universidad y los alumnos y alumnas que asisten a las lecciones que allí se imparten. En este caso, y como el propio cineasta señalara, La academia de las musas: "Es, efectivamente, una película de primeros planos. De rostros que se confrontan" (Liébana 2015). Pero a este respecto resulta especialmente interesante el filme En la ciudad de Sylvia y ello, por cuanto en él el cineasta barcelonés sitúa al personaje protagonista (Xavier Lafitte) en la terraza de un café donde éste comienza una actividad observadora. El protagonista del filme se hallará aquí con la mirada sumida en la multitud que le rodea observando minuciosamente los gestos y expresiones de las mujeres que se encuentran a su alrededor, deteniéndose en los detalles más triviales y permitiendo así que sean redescubiertos por el espectador (figs. 1, 2 y 3).

Esta escena del filme En la ciudad de Sylvia encuentra su correspondencia en la obra diarística de David Perlov. Se trata concretamente de las tomas realizadas por el cineasta de origen israelí a la terraza del café Polaco en Tel Aviv en dos ocasiones distintas (figs. 4, 5 y 6) durante una de las cuales la voz over de Perlov señala:

Esta filmación, esta búsqueda de imágenes provenientes de un sueño, me animan a salir. Trato nuevamente de contemplar rostros. Belleza y fealdad aún no me afectan. Es solo en los gestos donde hallo de vez en cuando cierto interés. En 


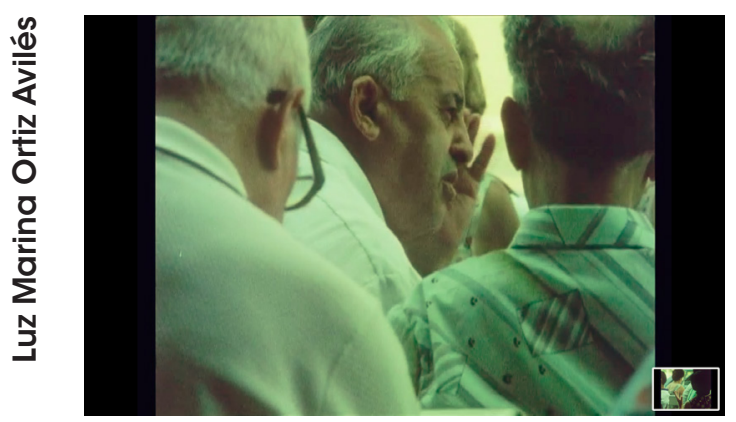

Fig. 5. David Perlov, Diary (1973-1983), Parte 1, 1974-1975

el café Polaco, ni siquiera escucho sus voces, su lengua. Es como trazar un boceto. Estas dos muchachas me agrada observarlas. Son naturales. Deseo observarlas más y más (Diary (1973-1983), Chapter 2)

David Perlov observa los rostros, gestos y expresiones de quienes se encuentran en la terraza del café Polaco y del mismo modo Guerin invita al espectador de En la ciudad de Sylvia a observar los rostros, gestos y expresiones de quienes se encuentran en la terraza del café TNS Le café. Aunque el filme de Guerin se trata de un largometraje al estilo convencional, el espectador participa activamente en la observación pues éste ocupará dos posiciones distintas como observador: por un lado, una posición externa al protagonista y, por otro, una posición que vendrá a sincretizar la mirada de ambos. Además, en el filme del cineasta barcelonés las imágenes vienen a suscribir las palabras de Perlov pues veremos al protagonista realizar bocetos ${ }^{10}$ de cuantos rostros y gestos llaman su atención (fig. 7).

A propósito del interés de ambos cineastas en el rostro hemos de señalar otra correspondencia entre sus obras; nos referimos al uso del sonido hablado como elemento para dirigir la atención del espectador hacia el aspecto físico del mismo, ello poniendo en sordina sus diálogos o directamente suprimiéndolos. En los diarios de Perlov es ejemplo de ello el retrato que hace a su amigo y maestro Joris Ivens. Durante el encuentro de ambos en el modesto apartamento que Ivens posee en Rue de Saints Pères, en París, Perlov filma al maestro en el balcón de su casa suprimiendo en el montaje el diálogo de aquel. Perlov asegura entonces estar escuchando a Ivens hablar en ho-

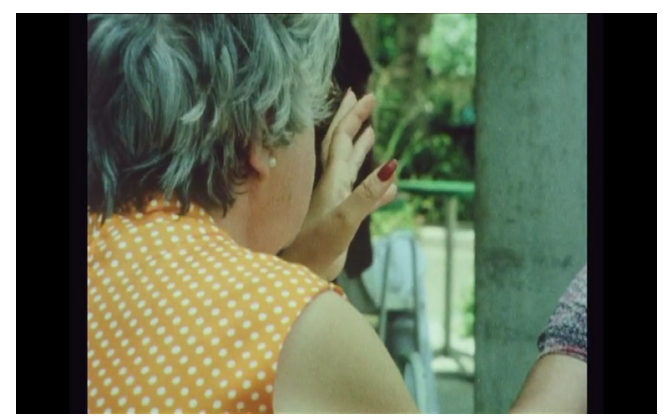

Fig. 6. David Perlov, Diary (1973-1983), Parte 1, 1974-1975

landés, como en el filme Zuiderzee (Ivens, 1930) de cuya banda sonora mientras tanto, escuchamos la música de Hans Eisler. También es ejemplo de ello el retrato que hará a su amigo enfermo Abrasza que, yacente sobre una cama en el reducido espacio de una habitación atestada de libros, insistirá a Perlov para que filme aquello que durante años ha estado contemplando: el techo de su habitación. La conversación entre ambos culminará con una vaga confidencia del enfermo a su amigo -esto es que no podrá soportar la enfermedad por más tiempo- que dará lugar más adelante en este diario -en agosto de 1981, cuando Perlov vuelve a París- a una triste secuencia, aquella en la que Perlov visita el hotel en el que su amigo decidiría poner punto final a todo aquel sufrimiento. Aunque en el momento de la filmación Perlov capta el significado de sus palabras -la determinación de su amigo- será durante el montaje de este diario cuando sobre aquellas imágenes acabe por vislumbrar el rastro de la muerte. De igual forma es ejemplo el retrato que Perlov realiza a Belka, una joven armenia descendiente de armenios a la que el cineasta pedirá que cante en dicho idioma. Cuando Belka finaliza la canción, Perlov se interesa por el significado de algunas palabras e inmediatamente después nos muestra, desde los ventanales del Hotel Mt. Hermon donde está teniendo lugar el encuentro entre el cineasta y la joven, una vista de la ciudad de São Paulo mientras volvemos a escuchar la canción en armenio que un instante antes veíamos interpretar a Belka; ello en una operación que logra transfigurar el lugar del presente (São Paulo) al lugar de la memoria de Belka (Armenia) para poner de relieve la añoranza de la tierra natal. Finalmente, y mientras aún dura la canción, 


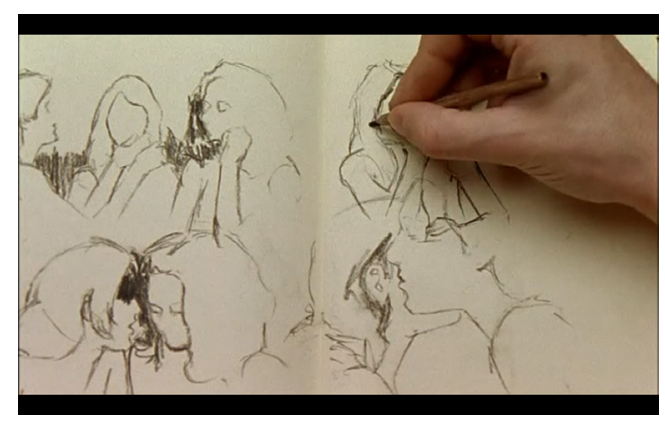

Fig. 7. José Luis Guerin, En la ciudad de Sylvia, 2007

la cámara de Perlov se detiene nuevamente en el rostro de Belka pero esta vez el diálogo de la joven ha sido suprimido. Estos y otros retratos mostrados en Diary (1973-1983) son presentados bajo esta misma fórmula, esto es con el diálogo en sordina, suprimido o simplemente en una lengua extranjera y desconocida.

Por su parte, también el cineasta barcelonés va a optar por esta fórmula en el filme En la ciudad de Sylvia. La ciudad de Estrasburgo, una ciudad fronteriza con Alemania y con gran afluencia turística, se convierte en el lugar idóneo para su filmación por cuanto se trata de una ciudad plurilingüe. Además, como Perlov, también Guerin va a presentar en ocasiones los diálogos en sordina o incluso los va a suprimir. A excepción del diálogo mantenido por los protagonistas durante el encuentro de ambos en el tranvía, el sonido hablado va a carecer de énfasis en el filme. Ya sea por el idioma, por recibirlos incompletos, por estar "situado" demasiado lejos de la fuente, etc., los diálogos van a resultar ininteligibles para el espectador de modo que lo único que realmente queda en la pantalla y el espectador puede captar son los rostros y los gestos de los hablantes.

En ambos casos -en los diarios de Perlov y el filme de Guerin- el efecto se aproxima a esa experiencia descrita por el crítico de arte y sociólogo John Ruskin de caminar por una ciudad extranjera donde no se tiene conocimiento del idioma. Dirá Ruskin:

Hay algo particularmente encantador en recorrer las calles de una ciudad de un país extraño sin comprender una sola palabra de todo lo que se dice. En tal caso, nuestros oídos se vuelven completamente imperturbables frente a los sonidos de las voces que nos circundan; el significado de las silabas no nos impide reconocer su carácter gutural, suave o meloso; y los gestos y ademanes, así como las expresiones faciales, tienen el mismo valor que una pantomima. Cada escena se convierte en una melodiosa ópera, o en una función de títeres (citado por Kracauer 2001, 148).

Efecto que S. Kracauer extiende en el cine al caso de los filme plurilingües, como son los dos casos que aquí nos encontramos analizando, donde a su juicio la diversidad de idiomas también aumenta el valor representativo de los gestos y expresiones pues al no conocer todas las lenguas el espectador las recibe no como mensaje sino como una configuración de sonidos que ininteligibles devuelven su atención hacia el aspecto físico de los mismos. Ambos cineastas, por tanto, hacen uso de la misma fórmula para instar al espectador a contemplar las imágenes -los rostros- con mayor intensidad al desplazar nuestra atención a las cualidades materiales del sonido hablado y realzar con ello su valor cinemático.

\section{La búsqueda de un rostro, su imagen- recuerdo}

Como venimos señalando, la fascinación de Perlov por el rostro humano lo impulsa en ocasiones a actuar como un espía que aguarda con su cámara el instante mágico de un gesto, una expresión, que le revele algo de alguien o que le permita tener una conexión con el otro. Pero lejos de limitarse en su diario a aguardar dicha revelación de forma pasiva, Perlov emprendería también la búsqueda de otros rostros. Es ejemplo de ello, en el capítulo cinco, cuando tras un largo paseo por la ciudad de París, Perlov vuelve a la calle donde vive su hija Yael y acude al Café Tabac de la esquina donde suele ir por las mañanas a disfrutar de lo que para él es una dulce ociosidad. Entonces su voz over nos explica: "Entro en el bar local con una sensación de alivio. Contento de ver gente. El sitio está lleno de espejos, pero quiero filmar sencillamente, directamente, no izquierda, no derecha. No blanco, no negro. Sé que hallaré lo que estoy buscando. Un rostro como éste" (Diary (1973-1983), Chapter 5).

O cuando situado en el espacio público de la calle junto a la salida de un servicio protestante trata de encontrar entre la multitud de africa- 
nos que salen del culto el rostro de su madrastra Dona Guiomar. La voz over de Perlov explica así la atracción maquinal-como involuntaria- de su cámara hacia la gente que se agolpa en la calle así como su actividad detectivesca al escudriñar los rostros de mujeres que se van presentando ante él -ante la cámara- en busca de un rasgo, una expresión, que le permita reconocer a la desaparecida: su madrastra. Dice Perlov:

Mi cámara se acerca más y más a la gente. Siento como si estuviera buscando a alguien. [ ] Recuerdo a Dona Guiomar mi madrastra negra leyéndome la Biblia cuando era pequeño. Yo comprendía muy poco y retenía solo algunas imágenes. Imágenes como la de las ovejas, las ovejas del Señor, la cual me agradaba y que nunca he visto en la vida real. Dona Guiomar era la única de la familia que usaba lentes. Comienzo a buscar un rostro como el de ella entre la multitud. ¿Sería como el de ella? ¿Como aquella? Seguramente era más joven. Ella jamás usó sombrero. Pero Dona Guiomar poseía la misma mirada punzante (Diary (1973-1983), Chapter 5).

El cineasta de origen israelí busca así el rostro de su madrastra pero no el rostro de aquella en el presente de la filmación sino el de su imagenrecuerdo, esto es un rostro más joven. Asimismo, en septiembre de 1977, durante un viaje que el cineasta realizaría a París con su hija Yael interesada en conocer las vivencias y amistades de su padre en la capital francesa, Perlov descubre la fisionomía de una joven que llama su atención. Aquella joven -explicaría el cineasta a su hija- no se trata de su vieja amiga Romaine pero tiene el mismo aspecto que aquella durante los años en los que Perlov vivió en París. Es decir, la imagen de la joven desconocida en el presente de la filmación se corresponde con la imagenrecuerdo que el cineasta guardaba de su amiga. A continuación en el diario, Perlov y Yael realizan una visita a Romaine; entonces, observando su rostro resulta inevitable hurgar en las huellas del tiempo tratando de desandarlas para vislumbrar en él los signos del rostro de la desconocida: el rostro de la joven Romaine. Perlov reflexiona así, pues, sobre la fugacidad del rostro y la fragilidad de la imagen-recuerdo, cuestiones estas sobre las que también Guerin va a reflexionar en su cine, concretamente en sus filmes En la ciudad de Sylvia y Unas fotos en la ciudad de Sylvia.
En En la ciudad de Sylvia, Xavier Lafitte deambula por la ciudad de Estrasburgo con el propósito de encontrar a Sylvia, una chica con la que tuvo un encuentro seis años antes en un bar de esta ciudad y de la que solo guarda su imagenrecuerdo. Durante el segundo día que transcurre en el filme, Lafitte, sentado en la terraza de una cafetería, es cautivado por una fisionomía -la de Pilar López de Ayala- que atrae toda su atención. En ese momento el protagonista olvida todo cuanto le rodea prestando atención únicamente al rostro que lo ha cautivado y ello hasta el punto de que cuando Pilar López de Ayala abandona el café, Lafitte se precipita tras ella recorriendo toda la ciudad. Dicha persecución se desplegará principalmente por el casco histórico de la ciudad de Estrasburgo hasta que suben a un tranvía donde tiene lugar el desencuentro de ambos. Será en ese elemento tecnológico que circula ajeno a todo cuanto acontece en la ciudad donde Lafitte descubra que Pilar López de Ayala no es la persona que creía, Sylvia.

Por su parte, Unas fotos en la ciudad de Sylvia también narra el encuentro entre un flâneur y una fugitiva; en este caso la búsqueda de una mujer con quien el director tuvo un encuentro (ficticio o no) veintidós años antes en un bar de Estrasburgo y de cuya experiencia trata de dar cuenta a través de su rememoración en primera persona como enunciador del filme. Para su búsqueda Guerin parte de la imagen-recuerdo de Sylvia mostrándonos los rostros femeninos de mujeres que le recuerdan a la desaparecida, es decir, se trata de la búsqueda de una mujer, de un rostro en una ciudad pero no del rostro de Sylvia en el presente de la filmación sino el de una mujer veintidós años más joven, el rostro de su imagen-recuerdo. También aquí, cuando una fisionomía cautiva toda su atención, Guerin se precipitará tras ella pero Unas fotos en la ciudad de Sylvia se trata de un fotomontaje secuencial por lo que dichas persecuciones son mostradas al espectador a través de una serie de fotografías.

La atracción irresistible de una fisionomía y la precipitación del protagonista o del cineasta tras ella -en En la ciudad de Sylvia y Unas fotos en la ciudad de Sylvia, respectivamente-, nos traen a la memoria el relato El hombre de la multitud de Edgar Allan Poe. En éste, un hombre obser- 
vador apasionado emprendía una persecución a través de las calles y bocacalles de la ciudad de Londres tras una fisionomía que había llamado su atención. En su ensayo El pintor de la vida moderna, Baudelaire reconocía en el observador apasionado del relato de Poe una forma diferenciada de flâneur pues este no se caracterizaba por un deambular con ritmo lento y cauteloso, ni su trayectoria venía marcada por el azar, sino que ambas cosas venían marcadas por la persona tras la cual se precipitaba y recorría la ciudad. Así, nos encontramos en el filme En la ciudad de Sylvia con la encarnación de este modelo de flâneur en la pantalla así como también en Unas fotos en la ciudad de Sylvia donde es el propio cineasta el que actúa como tal.

Ambos cineastas reflexionan, pues, sobre la fugacidad del rostro y la fragilidad de la imagenrecuerdo y también ambos lo hacen a través de una actividad detectivesca buscando en los gestos y expresiones de desconocidos los rostros del ayer. Sin embargo, mientras el protagonista de En la ciudad de Sylvia o Guerin en Unas fotos en la ciudad de Sylvia convienen una manifestación del modelo de flâneur de E.A. Poe, no ocurre así con Perlov que en ningún caso se precipita tras una fisionomía recorriendo la ciudad.

\section{David Perlov y José Luis Guerin, cineastas de la cotidianidad}

Perlov se convierte en su diario en un agente de lo cotidiano. Cansado de un cine profesional que ha dejado de atraerle acude al cine amateur ${ }^{11}$ para despojarse de las exigencias de los encargos -cada vez más herméticos y con más preceptos- así como también de los artificios del cine profesional que él mismo confiesa en una parte de estos diarios que tanto le gustaban antes. El inicio de estos diarios resulta a este respecto una declaración de intenciones pues en el comienzo del capítulo uno la voz over del cineasta explica así sus intereses: "Compro una cámara. Quiero comenzar a filmar por mi cuenta y para mí mismo. El cine profesional ha dejado de atraerme. Busco algo diferente. Quiero acercarme a lo cotidiano. Sobre todo, anónimamente. Lleva su tiempo aprender a hacerlo" (Diary (1973-1983), Chapter 1).
Perlov se compra una cámara de 16 mm con el propósito de filmar para sí mismo la cotidianidad de la ciudad pero también del hogar y el entorno familiar ${ }^{12}$. Así, el cineasta de origen israelí filmará a sus mellizas Noemí y Yael; primero, generalmente juntas, compartiendo un almuerzo o estudiando en casa; luego, la primera partida de aquellas del domicilio familiar tras ser reclamadas para hacer el servicio militar o ya independientes la una de la otra, enfrascadas en la cotidianidad de sus vidas, Noemí como profesora de danza y Yael como editora cinematográfica. Además filmará las visitas que las amistades del matrimonio realizarán al domicilio del cineasta en Tel Aviv -las conversaciones, las fiestas...- así como también las que el propio Perlov realizara a sus amigos y conocidos en París o Brasil, etc.

Por otro lado, como decíamos, también Perlov acudirá a la calle con su cámara atraído por la agitación y el movimiento de la vida en la ciudad. Una vez en el espacio público, armado con su cámara, Perlov descubre otra forma de ver las cosas. Así, en el capítulo dos, Perlov señala: "Aprendiendo a usar la cámara hallo un nuevo modo de ver las cosas. Comienzo a descubrir cosas que siempre han estado allí, a la vuelta de la esquina." (Diary (1973-1983), Chapter 2). El ojo objetivo de la cámara le permite, pues, romper con la ceguera que causa la cotidianidad. La cámara actúa como instrumento revelador al permitirle descubrir la realidad de su cotidianidad tomando conciencia de todo cuanto le rodea. Pero no sólo se referirá a aquello que el ojo objetivo de la cámara le permite captar -lo visible-, sino también a la banda sonora de la vida en la ciudad -lo audible-. Como señala el cineasta en el capítulo uno, también añadirá sonido a su diario siendo estos sonidos aquellos que caracterizan el espacio urbano que habita y transita, como son: el ruido generado por el tráfico, las bocinas de los vehículos, el ladrido de un perro, el chirriar de la puerta sobre la que un niño se balancea o la música que tan presente está en el hogar familiar.

El cineasta explora el nuevo instrumento y con él también el medio. Perlov abandona el artificio de la industria y encuentra en su hogar, los objetos, las personas, las calles y vistas de la ciudad el interés de un cine solitario que reivindica lo cotidiano, lo usual, esto es la vida. Como señalará 
el propio cineasta en el capítulo cinco su cine es un cine de hechos, un cine de realidad y no un cine de ilusión y mitificación y también así es el cine de Guerin que incluso en el artificio de la ficción deja espacio para la vida, introduce el azar y reclama lo cotidiano.

El interés de José Luis Guerin por lo banal, lo cotidiano, queda patente a lo largo de su filmografía. Desde sus largometrajes Los motivos de Berta, Tren de sombras (1997), En construcción, En la ciudad de Sylvia o La academia de las musas hasta su diario de registros Guest o sus cartas filmadas Correspondencia Jonas Mekas- J.L. Guerin, los trabajos del cineasta barcelonés se caracterizan por una fuerte presencia de lo cotidiano. Ya en su primer filme, Los motivos de Berta, Guerin utilizará la cotidianidad de una adolescente en el entorno rural que habita para narrar el teórico paso de aquella de la adolescencia a una cierta madurez. Elementos banales y cotidianos como la casa familiar, los juegos de infancia así como también los compañeros y lugares de juego, la bicicleta que utilizará para desplazarse, etc. caracterizarán a Berta a la vez que pondrán de relieve los cambios personales propios de quien se encuentra en tránsito entre dos periodos vitales. Asimismo, Guerin hará especial hincapié para la construcción del paisaje del filme en los sonidos cotidianos -el aleteo de una mosca, un ventilador, el ruido de un tractor, etc. -, elemento (el sonido) especialmente interesante en su filme $E n$ la ciudad de Sylvia donde el paisaje sonoro se constituye en una banda sonora de la vida en la ciudad. En su mayoría los sonidos y ruidos que la integran se desprenden de la actividad de sus gentes, de lo cotidiano y lo común de quiénes la habitan como son, por ejemplo: el ruido del tráfico, el timbre de una bicicleta, el chirriar de los tranvías que recorren la ciudad, los gritos de unos niños que corretean, el acordeón de un músico callejero, etc. Pero la cotidianidad no solo está presente en En la ciudad de Sylvia a través de la banda sonora del filme sino también en la actividad que llevará a cabo el protagonista del mismo; un viajero que atento a los movimientos, gestos y expresiones de quienes le rodean -fundamentalmente mujeres- va recogiendo en un cuaderno sus impresiones, como coleccionándolos. Igualmente ocurre en Guest donde Guerin deambula por las calles y espacios públicos de las distintas ciudades recogiendo con su pequeña videocámara las historias de la calle, atrapando trozos de vida. Entre los pequeños fragmentos de películas imaginadas destacan los que corresponden a un grupo de vecinos de un solar en Cuba, una familia de vendedores ambulantes en Lima, un grupo de mujeres en Cali o un grupo de niños en Samaria. De todos ellos se muestra la cotidianidad de sus vidas, lo común y banal como puede ser el tedioso día a día de una adolescente que comparte habitación con su madre y su perro Beethoven; las clases de salsa, impartidas en un más que reducido espacio, con que un paciente de VIH se gana la vida; el día a día en una chabola de una familia limeña que explican sus frustraciones vitales mientras preparan "cachanga"según la receta familiar de la abuela ya fallecida; o el día a día de unos niños que habitan en las ruinas de Samaria y que se esfuerzan en explicar a la cámara cómo era la escuela en la que ya no estudian y de la que apenas queda nada.

\section{La ceguera del artista}

Es ésta otra de las cuestiones sobre la que ambos cineastas van a reflexionar en su cine: la invidencia o el oscurecimiento en términos de creación artística.

Perlov, por su parte, se ve forzado a una situación de aislamiento al no recibir apoyo de los organismos oficiales israelíes. Esa situación lleva al cineasta a asumir su independencia con la compra de una cámara $16 \mathrm{~mm}$ que le permita trabajar por él mismo y para sí mismo como el propio cineasta señala al inicio de su diario. Sin embargo, asumir esta nueva realidad -su posición de cineasta independiente- no deja de ser una tarea difícil y delicada que llevará a Perlov a vivir un periodo de malestar tanto personal como artístico.

En el capítulo dos de este diario, que comprende los años 1978-1980 del mismo, Perlov trata de transmitir los sentimientos y emociones que fueron aflorando en su persona con cada propuesta rechazada, con cada proyecto rehusado que poco a poco iban minando su ánimo e incluso afectándole físicamente al verse por ello aquejado de insomnio. Cuando Perlov se dispone a registrar su estado de ánimo con imágenes advierte rápidamente la dificultad de dicha empresa: Nada 
le conmueve. Pero ¿cómo transmitir la desilusión, el desánimo o la apatía? La voz over del director, incluida posteriormente en el momento de la edición de este diario, vendrá a alumbrar aquellas imágenes de abatimiento y desconsuelo. Así, mientras el cineasta nos muestra algunas imágenes nocturnas del hogar familiar-vacías de presencias humanas-, el amanecer de la ciudad y los primeros viandantes en la calle, objetos que le traen a la memoria acontecimientos trágicos de su infancia en Brasil, planos de calles vacías, escenas callejeras como la celebración religiosa de Lag Ba'Omer que antes le atraían y ahora lo dejan indiferente o algunas tomas en picado del suelo del hogar familiar cuyas intersecciones utiliza para expresar con su valor metonímico lo difícil de la situación personal y artística que atraviesa -dice Perlov: "Estos pasajes son difíciles de traspasar" (Diary (19731983), Chapter 2)-, la voz over del cineasta nos asiste y arroja luz sobre aquellos difíciles capítulos de su vida al señalar:

Estoy exhausto. Exhausto de ¿cuántos, veinte años de energía malgastada, batallas frustrantes? Exhausto, desgastado, incapaz de dormir. Hoy contemplando nuevamente estas imágenes todo parece un árido desierto. El color de la arena. Horas que no transcurren. Busco sombra por todas partes. La luz del día irrumpe como una amenaza, trayendo consigo la consciencia de mi estado de ánimo (Diary (1973-1983), Chapter 2).

Todo este abatimiento y desconsuelo personal traen consigo el desánimo y desaliento artístico del cineasta. Su familia, afectada por la situación, tratará de animarlo, ayudarle a superar el bache, a "traspasar estos difíciles pasajes" sugiriendo al cineasta la realización de nuevos proyectos que finalmente no lograrán materializarse. Es ejemplo de ello cuando Mira lo incita a filmar un sueño. Perlov tratará de salir a la calle y buscar esas imágenes pero finalmente su búsqueda no tendrá éxito. Entonces el cineasta inserta la secuencia de su visita al oculista que en este instante tiene una fuerte carga metafórica pues la ceguera (temporal) de aquel ante las cosas tornan problemas físicos de visión a la vez que la voz over de Perlov revela: "Hace ya mucho que no veo realmente las cosas" (Diary (1973-1983), Chapter 2). Entonces, de forma totalmente excepcional en estos diarios, Perlov se convierte en objeto de filmación -ya no sujeto que filma tras la cámara- y su ojo no se tratará ya de un ojo que mira sino un ojo que será observado y examinado. Resulta muy significativa, pues, la inserción de esta secuencia en el diario por cuanto se trata de la única vez en él que el cineasta "se sienta" frente a la cámara. Ello eleva el valor de estas imágenes que cargadas de simbolismo vienen a subrayar el relato de su depresión así como el distanciamiento que el cineasta sufre respecto de las cosas y las personas en términos emocionales.

Mientras el doctor Pinkas examina el ojo izquierdo de Perlov aquejado de una "víbora"13, paciente y médico dialogarán sobre la afección - la gravedad de la misma, si se trata de algo hereditario, si requiere operación - resultando nuevamente relevante que durante la edición de este diario el cineasta optase por insertar esta secuencia con el diálogo original y ello, por cuanto como las imágenes también éste adquiere un valor simbólico que trasciende lo físico -el problema oftalmológico- y viene a inscribir el deseo del director: no otro que recuperar la visión, esto es encontrar una salida a la situación personal y artística que atraviesa. Ello queda reflejado en las palabras del doctor Pinkas que al final de la secuencia explica a Perlov:

La cirugía del ojo es un verdadero placer. [] He atendido casos de mucha gente que no veía. Yo los opero y al día siguiente vuelven a ver. Es como un nacimiento, es una sensación maravillosa, tanto para el paciente como para el doctor. Arrancarlos de la oscuridad o la ceguera y de pronto vuelven a ver bien. Pueden volver a pasearse y trabajar, es lo más importante (Diary (1973-1983), Chapter 2).

Entonces la precisión que el cirujano requiere para acometer con éxito su trabajo y devolver la visión a su paciente es puesta en relación por el cineasta con la precisión que requiere un pintor en la ejecución de su obra así como también la indispensable exactitud de su vista. Perlov acompaña sus reflexiones con las imágenes de algunos cuadros -o partes de ellos- de grandes Maestros como Picasso ${ }^{14}$, Van Gogh ${ }^{15}$ o Rembrandt con figuras tuertas, siendo la obra de este último, La conspiración de Claudio Civilis (1661-1662), la que simboliza las cavilaciones del director quien acaba por preguntarse si la pérdida del ojo esconde tras de sí la lucha del pintor por conti- 
nuar siendo creativo, así dirá Perlov: "¿Para luchar como este guerrero de Rembrandt?" (Diary (1973-1983), Chapter 2).

Por su parte, también Guerin reflexiona en su cine sobre la ceguera (temporal) del artista. Es ejemplo de ello su filme Guest. En este cuaderno de bitácora su paso por Nueva York se presenta como una excepción y ello por cuanto en él, Guerin, víctima de sus experiencias cinéfilas, es incapaz de ver nada al convertirse la ciudad en un evocación cinematográfica de otras películas. Su experiencia como espectador trasciende más allá de su estatuto de viajero. Así al deambular por el espacio público de la ciudad de Nueva York la yuxtaposición de películas evocadas impide al cineasta buscar nuevas historias que desarrollar. Esta alienación sufrida por el cineasta queda reflejada en la entrada del diario del jueves cuatro de octubre a través de imágenes abstractas de la ciudad de Nueva York -sus rascacielos-, acompañadas de un fragmento insertado del soundtrack del filme de Willian Dieterle Retrato de Jennie (Portrait of Jennie, 1948), precisamente aquel en que un pintor (Joseph Cotten) abatido por la falta de inspiración dice: "Nueva York es un lugar frío en invierno. $Y$ el invierno del treinta y cuatro no fue ninguna excepción. Pero existe un tipo de sufrimiento para el artista que duele más que el frío o la pobreza. Algo así como un 'invierno de la mente', el terrible sentimiento de la indiferencia del mundo".

Las imágenes abstractas de la ciudad de Nueva York y el soundtrack del filme de Dieterle ponen, pues, de manifiesto la circunstancia del cineasta a su paso por dicha ciudad. Pero no será esta la única referencia que encontremos en Guest a propósito de los temores a los que se enfrenta el artista sino que también va a poner de relieve un delicado momento del proceso creativo, esto es la crisis de la página en blanco. Ello tiene lugar en Guest a través de las imágenes de un cuaderno abierto con las páginas en blanco situado junto al estuche de una cinta de video en el que aparece escrita la palabra film. Estas imágenes serán recurrentes posteriormente en Correspondencia Jonas Mekas-J.L. Guerin, en este caso con la imagen de un cuaderno abierto con las páginas en blanco donde también aparece escrita la palabra film mientras se oye la voz over de Guerin que dirigiéndose a Mekas señala: "Estoy rumiando su carta en un bar de estación de tren, en el bar restaurant de la Gare de Lyon" (Carta a Jonas mekas $n^{\circ} 1$ ) o la imagen de una pantalla de cine en blanco que aguarda la escritura cinematográfica, en Carta a Jonas Mekas $n^{\circ} 4$. En ambos casos el cineasta barcelonés pone de manifiesto ese delicado momento del proceso creativo, cuando aún no hay nada escrito -ya sea escritura literaria o cinematográfica pues a tales efectos es indiferente la disciplina-. No obstante, como señalara Guerin en una entrevista, esa crisis de la página en blanco en su caso no lo es tanto por una falta de inspiración como por un exceso de motivación. El cineasta barcelonés lo explicaría así:

A veces me sucede como dicen que les pasa a los dromedarios en el desierto, que no se mueven, y no por falta de estímulos sino al contrario por un exceso de estímulos. Cualquier punto en el horizonte es estimulante, y el resultado es que el dromedario no se mueve. Entonces incluso que te den un espacio, como aquí: me han puesto un cubo con unas paredes y a partir de ahí puedo inventar cosas (De Pedro 2007).

\section{Conclusión}

David Perlov y José Luis Guerin convergen en su entendimiento del medio cinematográfico como una forma de escritura, comparten sus intereses como cineastas e incluso presentan ciertos paralelismos en su discurrir personal y profesional. Ambos cineastas encuentran en el cine artesanal el refugio que el cine en relación con lo industrial no les ha dado, ambos llevan a cabo proyectos de naturaleza similar como los filmes rodados con la ayuda de sus alumnos, los filme-viaje o los filmes realizados a partir de fotografías tomadas por los propios directores con anterioridad y ambos combinan su actividad como cineastas con una labor docente. Tanto Perlov como Guerin asumen, como cineastas, la práctica del flâneur adoptando cada uno en su tiempo la tecnología a su alcance que le permitiera una mayor libertad de movimiento así como una mayor invisibilidad en lo que a la actividad observadora se refiere, como era propio de este tipo social. Además, como decimos, Perlov y Guerin comparten sus intereses como cineastas pues ambos van a sentir fascinación por los rostros hasta el 
punto de interesarse en el cine como un arte del retrato utilizando el medio para llevar a cabo una reflexión en torno a la fugacidad del rostro y la fragilidad de la imagen-recuerdo. También ambos van a reivindicar con su cine lo cotidiano, lo usual, lo banal, esto es la vida misma sin artificios o van a reflexionar sobre un delicado momento del proceso creativo: la crisis de la página en blanco, así como también la ceguera temporal del artista.

Sus cinematografías concurren no en tiempo ni lugar pero sí en aquello que mueve o motiva su trabajo, presentándose la obra del cineasta de origen israelí a este respecto como un preludio -en el sentido de dar comienzo- de la obra de Guerin en la que reaparecen algunos elementos y rasgos de aquella aunque trabajados, eso sí, desde el estilo personal del cineasta barcelonés. Así pues, no pueden verse los paralelismos entre las obras de ambos como un sucursalismo de la obra de Guerin respecto de la de Perlov, sino como un influjo de esta última en la del cineasta barcelonés, que se percibe como ecos de aquella. 


\section{NOTAS}

1 En España, por ejemplo, desde 2005 esta obra monumental va circulando por festivales (como Punto de Vista, de Pamplona, o Festival Primera Persona organizado por el Centro de Cultura Contemporánea de Barcelona (CCCB)). Además el CCCB se ha encargado, a través de XCèntric, de dar a conocer no solo Diary (1973-1983) sino también algunas de las obras del director filmadas entre 1953 y 2003 como son In Jerusalem, In Thy Blood Live y Biba que aún permanecen desconocidas. Asimismo, la edición en DVD de la distribuidora francesa Re-voir ha ayudando a su difusión en nuestro país.

2 Fue uno de los organizadores de la retrospectiva que el Centro Pompidou dedicó a Perlov en 2006.

3 Filmado durante más de 10 años, Diary (1973-1983) consiste en seis capítulos de una hora cada uno aproximadamente.

4 También conocida como Revised Diary (1990-1999).

5 El guión para Anemones fue primero concebido por David Perlov como dibujos cuando a finales de los años cincuenta la Sociedad para la Protección de la Naturaleza le encargó un filme. El proyecto finalmente no saldría adelante y cincuenta años después, basándose en los mismos dibujos, Perlov realizaría el filme junto con sus alumnos de la Universidad de Tel-Aviv y un actor invitado.

6 Dice Perlov: "el pueblo de mi adolescencia. La inmensa ciudad" (Diary (1973-1983), Chapter 6)

7 Como Diary (1973-1983), Guest está filmado desde distintos lugares. Las ciudades que componen el itinerario al completo de 2007 a 2008, en orden cronológico de visita, son: Venecia, Madrid, La Coruña, París, Marsella, Bogotá, Santa Marta, Vancouver, Nueva York, Madrid, São Paulo, Macao, París, Estrasburgo, París, Santiago de Compostela, Gijón, Belford, La Habana, Valencia, Londres, Palms Spring, Los Ángeles, Rötterdam, Ámsterdam, Harvard, Pamplona, México D.F., Miami, Las Palmas de Gran Canarias, Nantes, Hong Kong, Cali, Buenos Aires, Tubingem, Stuttgart, Lisboa, Jeonju, Seúl, Palma de Mallorca, Edimburgo, Madrid, Jerusalén, Wroclaw, Lima, Cuzco, Santiago de Chile y Venecia. No obstante, no todas formarían parte del filme finalmente.

8 Señalará el cineasta "No recuerdo haber visto corbatas en aquellos tiempos. No recuerdo haber visto sonrisas." (Perlov, Diary (19731983), Chapter 6)

9 Estrasburgo, Florencia, Madrid, Lisboa, Mallorca, Marsella, Bolonia y Aviñón en Unas fotos en la ciudad de Sylvia y nuevamente Estrasburgo en En la ciudad de Sylvia.
10 Los dibujos son realizados por Joaquín Jara (Sabadell, 1977). La colaboración de Jara en el filme de Guerin no es por casualidad sino fruto de sus intereses como artista pues su obra confluye en una temática común, esto es el género del retrato como un proceso creativo, siendo también el rostro y su retrato, como vemos, una cuestión extensamente abarcada en la obra de Guerin. "Joaquín Jara". Miscelanea, acceso junio 6, 2019, https://www.miscelanea.info/a40/joaquin-jara

11 Entendido amateur, como indica Labayen: "En el sentido latino del vocablo. Es decir el amateur como amante y, por lo tanto, creador de un cine personal donde deposita lo más íntimo de sí mismo." Fernández Labayen, Miguel. "Jonas Mekas y el problema de la verdad: reflexiones en torno a lo real." en Puntos de vista. Una mirada poliédrica a la historia del cine, ed. Daniel Aranda, Meritxell Esquirol y Jordi Sánchez-Navarro (Barcelona: Editorial UOC, 2009), 131.

12 Para la realización de Updates Diary (1990-1999) Perlov optaría por una cámara de video más ligera.

13 Una afección de la membrana mucosa de la conjuntiva que penetra en la córnea y puede producir alteraciones de la misma.

14 Se trata del cuadro Celestina (Picasso, 1903).

15 Se trata del cuadro Retrato de un hombre tuerto (Van Gogh, 1888). 


\section{REFERENCIAS}

Astruc, Alexandre. "Nacimiento de una nueva vanguardia: la "Caméra-stylo»." En Textos y manifiestos del cine, editado por Joaquín Romaguera y Homero Alsina, 219-224. Madrid: Cátedra, 1989.

Merino, Imma. "La vida y nada más." La Vanguardia, Marzo 28, 2007. http://hemeroteca. lavanguardia.com/preview/2008/07/16/pagina-28/56809019/pdf.html?search=perlov

Fernández Labayen, Miguel. "Jonas Mekas y el problema de la verdad: reflexiones en torno a lo real." En Puntos de vista. Una mirada poliédrica a la historia del cine, editado por Daniel Aranda, Meritxell Esquirol y Jordi SánchezNavarro, 121-136. Barcelona: Editorial UOC, 2009.
Klein, Irma, y Uri Klein. "An interview with David Perlov (excerpts)." En Diary: David Perlov. Diary (1973-1983) [DVD]. Francia: Re-Voir Video, 2006.

Kracauer, Siegfried. Teoría del cine. La redención de la realidad física. Barcelona: Paidós Ibérica, 2001

Liébana, Raúl. "Entrevista a José Luis Guerin, director de La academia de las musas." El espectador imaginario 68, Diciembre, 2015. http:// www.elespectadorimaginario.com/laacademia-de-las-musas/

Pedro, Gonzalo de. "Ni yo mismo sé si esto es una película." Público, noviembre 27, 2007. www. publico.es/21656/ni-yo-mismo-se-si-esto-esuna-pelicula 
